\title{
Solitary Fibrous Tumor in Retroperitoneum ${ }^{1}$
}

\author{
Jeong Sik Yu, M.D., Ki Whang Kim, M.D., Eun Kyung Kim, M.D. \\ Byung Chul Kang, M.D., Hyeon Joo Jeong, M.D.2
}

The solitary fibrous tumor, of rare mesodermal origins, primarily affects the pleura and occasionally occurs in the peritoneum and at nonserosal sites. Although this is a pathologically well established entity, it is frequently confused radiologically and pathologically with other tumors of mesenchymal origin. We report one case of a solitary fibrous tumor in the retroperitoneum. The $15 \times 10 \times 7$ $\mathrm{cm}$ mass, located in the left perirenal space just above the left kidney, had relatively homogeneous consistency and was well-delineated from surrounding organs in CT and MR images. It showed intense, gradual, centripetal enhancement during dynamic scans, and partially unenhanced areas which matched the high signal intensity portions in T2 weighted MR images, pathologically correlated to myxoid degeneration. Although not specific, when a large, well-delineated mass of strong contrast enhancement with lack of massive necrosis is encountered, solitary fibrous tumor must be included in the differential diagnosis of a retroperitoneal soft tissue mass.

\author{
Index Words : Fibroma \\ Retroperitoneal space, neoplasms \\ Retroperitoneal space, CT \\ Retroperitoneal space, MR
}

The solitary fibrous tumor, of rare mesodermal origins, primarily affects the pleura and occasionally occurs in the peritoneum and at nonserosal sites $(1-3)$. Although this is a pathologically well-established entity, it is frequently confused radiologically and pathologically with other tumors of mesenchymal origin $(1-3)$. We report a solitary fibrous tumor in the retroperitoneum that presented as a soft tissue mass inside the renal fascia. To our knowledge, this is the first reported case of a solitary fibrous tumor seen on $\mathrm{CT}$ and MR imaging in the retroperitoneum, and correlating with pathologic findings.

\section{CASE REPORT}

A 57-year-old woman had for ten days suffered pain

\footnotetext{
${ }^{1}$ Department of Diagnostic Radiology, Yonsei University College of Medicine

${ }^{2}$ Department of Pathology, Yonsei University College of Medicine

Received June 28, 1996 ; Accepted September 4,1996

Address reprint requests to: Jeong Sik Yu, M.D., Department of Radiology,

YongDong Severance Hospital, \# 146-92, Dokok-Dong, Kangnam-Ku, Seoul,

135-270, Korea. Tel. 82-2-3450-3515 Fax. 82-2-562-5472
}

of the left flank. She was admitted because of a mass in that flank discovered during ultrasonography at local clinic. She had no specific past or family history of disease. The routine $\mathrm{CBC}$ and urinalysis laboratory data were within normal limits, and she appeared well upon admission.

Sonography showed a well-defined, homogeneously echogenic, large, round mass in the left adrenal gland area which was well separated from the left kidney. The mass showed internal high vascularity on color Doppler imaging. CT scans of the lesion demonstrated a huge mass located on the posterior aspect of the pancreatic tail which contained no visible calcification on pre-contrast scan and measured about 42 Hounsfield units. A gradual, centripetal contrast filling was demonstrated in the mass during dynamic contrast enhanced scan. The degree of contrast enhancement was as high as in the renal cortex(Fig. 1a). MR showed intermediate signal intensity similar to that of muscle on T1-weighted images and high-intensity signal on T2-weighted images(Fig. $1 \mathrm{~b}$ and 1c). Multifocal tubular or branching patterned higher signal intensities were also visualized on T2-weighted images(Fig. 1c). Con- 
trast enhancement with gadopentetate dimeglumine produced a marked heterogeneous gradual enhancement in the dynamic protocol. Delayed or unenhanced compartments in post-contrast images were well matched with the tubular or branching high signals in the
T2-weighted images(Fig. 1c and 1d). The characteristic$s$ of this huge, highly enhancing mass in the retroperitoneum led us to believe that it was a tumor with high vascularity, such as pheochromocytoma, malignant fibrous histiocytoma, undifferentiated liposarcoma, ma-
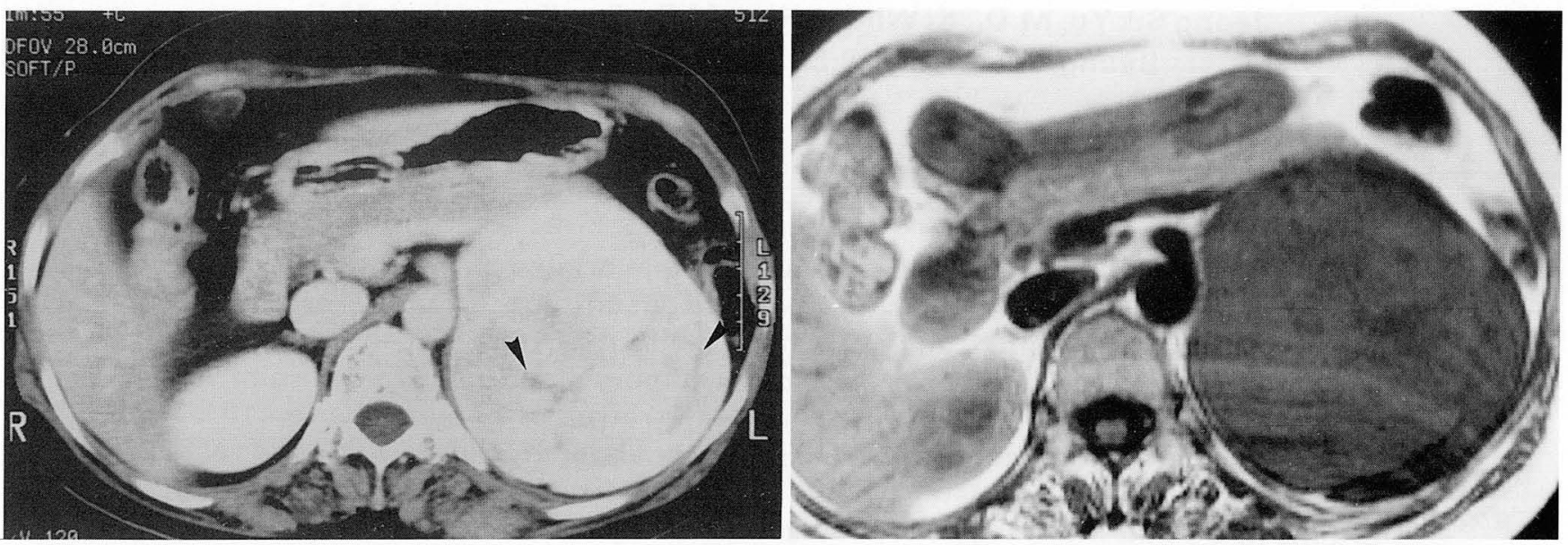

a

b
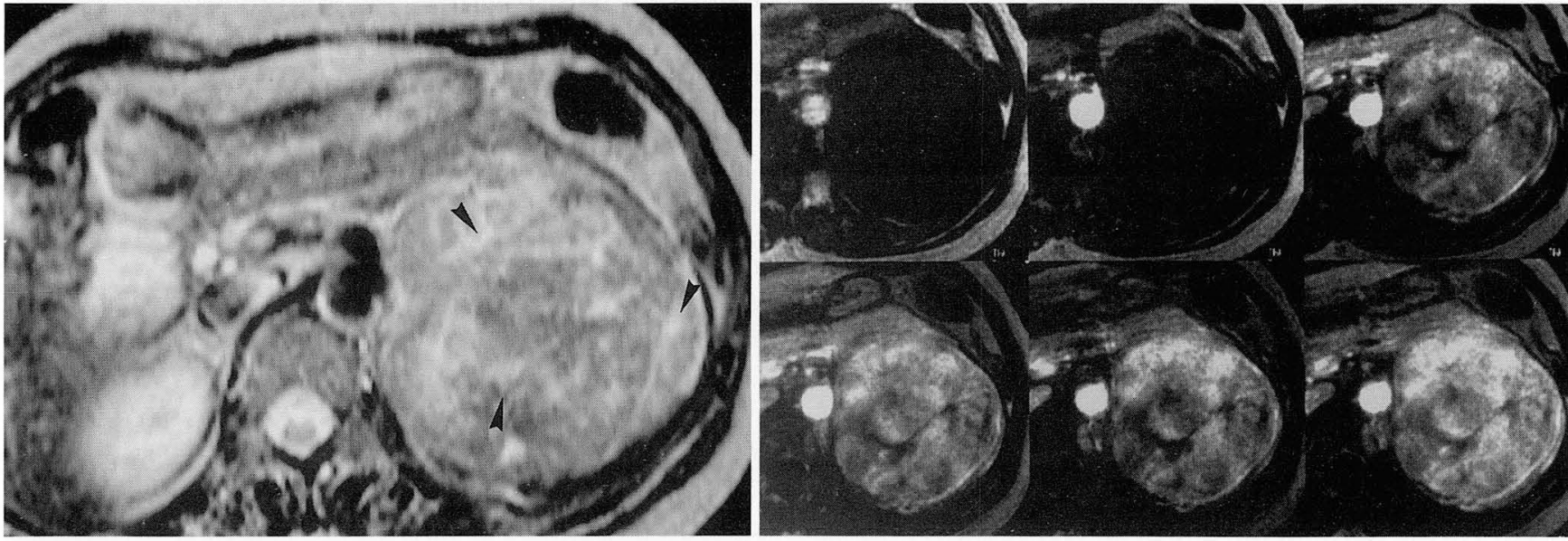

c

d

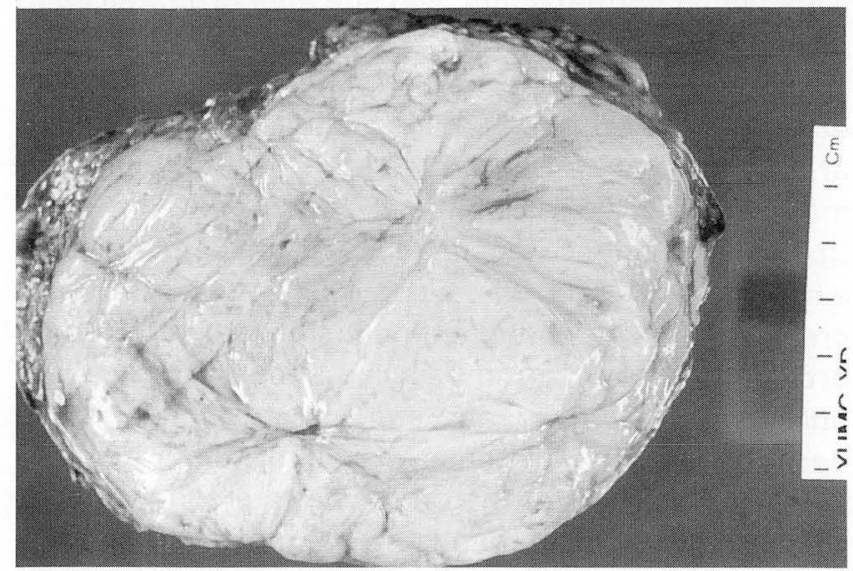

Fig. 1. Solitary fibrous tumor arising from left perirenal space in a 57-year-old woman.

a. Enhanced CT scan in equilibrium phase shows large lesion occupying left retroperitoneal space posterior to the tail of pancreas. High-attenuation areas prevail in lesion, al though portions of low attenuation are demonstrated(arrowheads).

b. T1-weighted(500/15) MR image shows low signal intensity mass. c. T2-weighted(1801/90) MR image shows heterogeneous signal in- $\xi$ tensity mass. Multiple tubular and branching-patterned high-intensity signals are noted(arrowheads).

d. Dynamic MR imaging using gradient echo(70/6/80 $)$ technique shows gradual, inhomogeneous enhancement of tumor(from upper left to lower right ; before, $20 \mathrm{sec}, 80 \mathrm{sec}, 140 \mathrm{sec}, 200 \mathrm{sec}, 260 \mathrm{sec}$ ). Multiple unenhanced portions matched to low attenuation areas in the enhanced CT and high-intensity signals in the T2-weighted MR images, denoting areas of myxoid degeneration, are also seen. The overt inhomogeneity of enhancement in arterial phase originated from the regional difference of cellular densities.

e. Cut slice of gross specimen reveals a greyish white fibrotic lesion intermingled with multiple tubular or branching-patterned foci of myxoid degeneration. 
lignant hemangiopericytoma or Castleman disease.

Evaluation of a surgically-excised pathologic specimen revealed a huge, round, solid mass with firm consistency, measuring $15 \times 10 \times 7 \mathrm{~cm}$ and weighting 700 grams, without a definite capsule. A $4 \times 1.5 \mathrm{~cm}$ fragment of adrenal gland was attached to one side. On the cut section, the main component of the tumor was greyish white and homogeneously fibrotic(Fig. 1e). On microscopic examination, areas of myxoid degeneration were demonstrated. There was no necrosis, mitosis or cellular dysplasia. Vascular structures were scattered throughout the lesion, with hyalinization of the vessel wall and stroma, and there were wavy tumor cells suggesting the possibility of a pathological neurogenic tumor. Immunologic staining of the tumor cells, however, showed a positive reaction on CD34(anti-HTCA-1) and vimentin, but cytokeratin and $\mathrm{S} 100$ protein consistently reacted negatively, thus confirming that the mass was a solitary fibrous tumor simulating the counterpart of pleural or mesenteric origins.

\section{DISCUSSION}

Reports of CT or MR findings of solitary fibrous tumors have been very limited, even in pleural lesions $(4-7)$. The significant enhancement always shown on enhanced CT or MR scans has been explained by the vascularity of the tumor, which frequently shows myxoid degeneration and sometimes contains hemorrhage or cystic degeneration, as seen in the low density or non-enhancing portion of enhanced scans. In this case, the tubular or branching pattern of low signal intensity in dynamic MR images was well-matched with myxoid degeneration.

When a huge, highly-enhanced, well-delineated, relatively homogeneous solid mass is encountered in the retroperitoneum, it is hard to differentiate tumors of varying mesenchymal origin, including malignant fibrous histiocytoma or undifferentiated liposarcoma(8). Nonfunctioning extra-adrenal paraganglioma, hemangiopericytoma, or Castleman disease should also be included in the differential diagnosis. In this case, the mass was located in the perirenal space just above the left kidney, and the adrenal gland was not identified in the images so we could not exclude the possibility of nonfunctioning pheochromocytoma, originating from the left adrenal medulla. The point of radiological differential diagnosis was dependent on the patients age, overall incidence, detailed anatomic location, tendency to calcify, internal necrosis, hemorrhage, invasion be- yond the capsule or distant metastasis. In this case, the lesion showed no prominent necrotic portion or large cystic component in spite of its relatively large size (long diameter $=15 \mathrm{~cm}$ ). It also had no demonstrable calcification. A well-defined margin without local invasion or distant metastasis also suggested it was benign. Radiologic findings were similar to previously reported cases of pleural origin benign solitary fibrous tumors. With regard to histologic findings, the absence of mitotic activity excluded other malignant spindle cell tumors of malignant fibrous histiocytoma, malignant hemangiopericytoma, or fibrosarcoma. Specific immune stainings also excluded tumors originating from the neural crest. We think that the numerous mediumsized blood vessels, open with hyalinized walls, and partially-collapsed branching vessels can explain the gradual high centripetal contrast enhancement seen on dynamic CT and MR scans. Although not specific, when a large, well delineated mass of strong contrast enhancement with lack of massive necrosis is encountered, solitary fibrous tumor must be included in the differential diagnosis of a retroperitoneal soft tissue mass.

\section{REFERENCES}

1. Briselli M, Mark EJ, Dickersin R. Solitary fibrous tumors of the pleura: eight new cases and review of 360 cases in the literature. Cancer $1981 ; 47: 2678-2689$

2. Hanau CA, Miettinen M. Solitary fibrous tumor: histological and immunohistochemical spectrum of benign and malignant variants presenting at different sites. Hum Pathol 1995;26: 440-449

3. Suster S, Nascimento AG, Miettine M, Sickel JZ, Moran CA. Solitary fibrous tumor of soft tissue: a clinicopathologic and immunohistochemical study of 12 cases. Am J Surg Pathol $1995 ; 19: 1257-1266$

4. Dedrick CG, McLoud TC, Shepard JO, Shipley RT. Computed tomography of localized pleural mesothelioma. AJR 1985;144 :275-280

5. Mendelson DS, Meary E, Buy JN, Pigeau I, Kirschner PA. Localized fibrous pleural mesothelioma:CT findings. Clin Imaging $1991 ; 15: 105-108$

6. Lee KS, Im JG, Choe KO, Kim CJ, Lee BH. CT findings in benign fibrous mesothelioma of the pleura:pathologic correlation in nine patients. AJR $1992 ; 158: 983-986$

7. George JC. Benign fibrous mesothelioma of the pleura:MR findings. AJR 1993; $160: 204-205$

8. Lane RH, Stephens DH, Reiman HM. Primary retroperitoneal neoplasms:CT findings in 90 cases with clinical and pathologic correlation. AJR 1989;152:83-89 


\section{후복막강내 고립 섬유성 종양1}

1 연세대학교 의과대학 진단방사선과학교실

2 연세대학교 의과대학 해부병리과학교실

\section{유 정 식·김 기 황·김 은 경·강 병 철·정 현 주 2}

드문 중배엽 기원의 고립 섬유성 종양은 늑막에서 발생하는 것으로 되어 있지만 복막에서 또는 장막에 싸여있지 않은 부 위에서도 간혹 보고되고 있다. 병리학적인 분류는 잘 이루어져 있으나 방사선학적으로나 병리학적으로도 다른 중배엽기원 의 종양과 감별이 어려운 경우가 적지 않은 것으로 알려져 있다. 저자들은 후복막강내 발생한 고립 섬유성 종양 1 예를 경험 하였기에 보고하는 바이다. CT와 MR상에서, 좌측 신장 직상방으로 $15 \times 10 \times 7 \mathrm{~cm}$ 크기의 종괴가 주변조직과 명확하게 분리 되어 보였고 내부는 비교적 균질했으며 조영증강시에 주변부로부터 중앙부로 차들어오는 점진적인 강한 조영증강을 보였 다. 일부 조영증강이 되지 않은 부분은 T2 강조영상에서 고신호강도의 부위과 일치하였고 병리조직학적으로는 점액성 변성 부위와 일치하였다. 비특이적이기는 하지만, 크기에 비해 내부에 괴사가 없고 과혈관성이며 악성종양의 증거가 없는 종괴가 있을 때, 후복막강에서도 이 질환을 감별진단의 하나에 포함시켜야 할 것으로 본다. 